\title{
LABOR LAW: NLRB HOLDS GOVERNMENT INTERVEN- TION A BAR TO REPRESENTATION ELEGTION IN AEROSPACE INDUSTRY
}

A N ELECTron petition filed by a rival union seeking to replace a
certified bargaining representative often reveals a conflict between
two National Labor Relations Act policies-employee freedom of
self-organization and the stabilization of industrial relations through
collective bargaining. In order to reconcile these cross-purposes of
the act, Congress and the National Labor Relations Board have
acted to regulate the timeliness of election petitions. The Taft-
Hartley amendments to the act, for example, provide that election
petitions will not be entertained when filed within one year after a
previously conducted election in the bargaining unit. ${ }^{2}$ The Board,
utilizing the broad power delegated to it by Congress to administer
the act, ${ }^{3}$ has promulgated rules that prohibit, in most instances,
entertainment of an election petition filed where there is a valid
collective bargaining contract ${ }^{4}$ existing between the employer and
the certified bargaining representative..$^{5}$ The latter rule, known as

${ }^{1}$ Compare National Labor Relations Act $\$ 1$, 61 Stat. 136 (1947), 29 U.S.C. $\$ 151$ (1958) with $\S 7$ of the act, 61 Stat. 140 (1947), 29 U.S.C. $§ 157$ (1958). See generally Milis \& BRown, From the Wagner Act to TaFt-Hartuty 155 (1950); Daykin, The Contract as a Bar to a Representation Election, 10 LAB. L.J. 219 (1959); Fcldesman, Contract Bar to Representation Elections, 29 GEO. WASH. L. REv. 450 (1960); Friedin, The Board, the "Bar," and the Bargain, 59 Colum. L. REv. 61 (1959); Lahne, The Duration of Labor Agreements and the Contract Bar Doctrine of the National Labor Relations Board, 5 SYRAcUse L. REv. 146, 147 (1954); Naumoff, The New NLRB Contract Bar Rules (A Summary and Evaluation), N.Y.U. 12TH ANNUAL CONF. ON LAB. 253 (1959); Van Arkel, Twenty Years of the NLRB: Unit and Contract Bar Problems in Representation Cases, 16 OHro ST. L.J. 360 (1955).

${ }^{2}$ Labor Management Relations Act $\$ 9(e)(3)$, 61 Stat. 145 (1947), 29 U.S.C. § 159 (e) (3) (1958).

${ }^{3}$ National Labor Relations Act $\$ \$ 6,9$ (b)-(c), 61 Stat. 140, 143.44 (1947), 29 U.S.C. $\S \S 156,159$ (b)- (c) (1958).

- To act as a bar the contract must be in writing, be signed by the parties, and contain sufficient terms and conditions of employment to gnide adequately the day-to-day bargaining relationship. Appalachian Shale Prods. Co., 121 N.L.R.B. 1160 (1958). The collective agreement must be complete and final, not mercly temporary, to act as a bar. See, e.g., Pacific Coast Ass'n of Pulp \&: Paper Mrfrs., 121 N.L.R.B. 990 (1958); Remington Rand Corp., 120 N.L.R.B. 1294 (1958).

${ }^{5}$ Contracts have been refused bar status when they contained a clause which was either illegal on its face or had previously been declared illegal in an unfair labor practice proceeding. Sce, e.g., Gary Sted Supply Co., 144 N.L.R.B. No. 45 (1963) (check-off clause); Paragon Prods. Corp., 134 N.L.R.B. 662 (1961) (union sccurity clause). But see Food Haulers, Inc., 136 N.L.R.B. 394 (1962) (contract accorded bar status despite hot-cargo clausc). A substantial increase in the working force during 
the contract bar rule, ${ }^{6}$ bars an election petition filed by a rival union until expiration of the contract or until the maximum bar period of three years from the date of execution of the contract has expired. ${ }^{7}$

In Aerojet-General Corp., the NLRB formulated a new bar rule concerning the timeliness of rival union election petitions in the aerospace industry. ${ }^{9}$ The Board held that federal government intervention in collective bargaining between a prime producer of missile components and the certified bargaining agent, barred an election petition filed by a rival union even though no contract existed at the time of filing. ${ }^{10}$

In Aerojet, the United Missile and Aerospace Technicians (UMAT), an independent union formed by dissident employees at the Aerojet-General Corporation, ${ }^{11}$ filed a petition for an election

the life of the contract may prevent it from acting as a bar. General Extrusion Co., 121 N.L.R.B. 1165 (1958). The existence of a union schism may have the same effect. Hershey Chocolate Corp., 12I N.L.R.B. 90I (1958). A new, independent business operation will prevent a prior contract from acting as a bar, Buy Low Supermarket, Inc., 131 N.L.R.B. 23 ( 1961 ), but a mere expansion of an old operation will not. Simmons Co., 126 N.L.R.B. 656 (1960).

'The Board first clearly articulated the policy that an industrial contract would bar an election in National Sugar Ref. Co., 10 N.L.R.B. 1410 (1939). See MiLlis \& Brown, op. cit. supra note 1 , at 156 .

7 The collective agreement is a bar for a reasonable length of time. See, e.g., Reed Roller Bit Co., 72 N.L.R.B. 927 (1947) (two year contract bar for full term though duration longer than customary in industry); Owens-Illinois Pac. Coast Co., 36 N.L.R.B. 990 (1941) (two year contract bar for full term when duration customary in industry). To avoid burdensome administrative difficulties, the maximum reasonable duration of a contract bar was fixed at two years in Pacific Coast Ass'n of Pulp \& Paper Mfrs., I21 N..R.B. 990 (1958), and was extended to three years in General Cable Corp., I39 N.L.R.B. 1123 (1962). A thirty-day period beginning nincty days before expiration of the contract or the maximum bar period is reserved during which time election petitions may be filed by rival unions and accepted as timely. The sixty days preceding expiration is an insulated period during which election petitions are considered untimely and dismissed. Leonard Wholesale Meats, Inc., 136 N.L.R.B. 1000 (1962), modifying Deluxe Metal Furniture Co., 12I N.L.R.B. 995 (1958).

${ }^{8}$ I 44 N.L.R.B. No. 42, 4 CCH LAB. L. Rep. (63-2 CCH NLRB) I 12547 (Sept. 3, 1963).

- By explicitly limiting the decision to the facts of the Aerojet case, the Board did not commit itself to any future application of the new policy in the areospace industry. Sec note 36 infra and accompanying text.

${ }^{10}$ The contract bar rule is administrative in nature and courts generally will not interfere with the Board's application of the rule. NLRB v. Libbey-Owens-Ford Glass Co., 241 F.2d 831 74th Cir. 1957); NLRB v. Grace Co., 184 F.2d 126 (8th Cir. 1950); Local 492, Bakery Workers v. Schauffer, I62 F. Supp. 12I (E.D. Pa. I958).

${ }_{11}$ Brief for Intervenor (IAM), p. 2; Brief for Petitioner (UMAT), p. 11. The IAM contended that the UMAT was not a labor organization because it lacked the indicia of a labor organization as set forth in $\$ 201$ (a) of the Labor Management Reporting and Disclosures Act (Landrum-Grifin Act), 73 Stat. 524 (1959), 29 
some five months after the old contract between the employer and the International Association of Machinists (IAM) had expired and over one week before these same parties executed a new collective bargaining agreement. ${ }^{12}$ Early in the five month interim bargaining period, President Kennedy, concerned about the prospect of a strike in this vital defense industry, asked for, and received, a sixty day no-strike pledge from the IAM. ${ }^{13}$ The President appointed a commission to study the dispute during this sixty day period and to make suggestions for its solution..$^{14}$ Despite these efforts, the impasse continued and the employees struck the company. ${ }^{15}$ At the insistence of the Secretary of Labor, the strike was halted after two days, and negotiations were continued in his office.10

U.S.C. \$ 431 (a) (Supp. IV, 1963). Both the Regional Director and the Board rejected this contention and stated that in $\S 603$ (b) of the Landrum-Griffin Act, 73 Stat. 540 (1959), 29 U.S.C. $\S 523$ (b) (Supp. IV, 1963), Congress clearly manifested its intent that provisions of the Landrum-Griffin Act should not impair the operation of the National Labor Relations Act. The UMAT was found to meet the qualifica. tions of a labor organization as set forth in $\$ 2(5)$ of the National Labor Relations Act, 61 Stat. 138 (1947), 29 U.S.C. § $152(5)$ (1958). See, e.g., Alto Plastics Mfg. Corp., 136 N.I.R.B. 850 (1962); Hamilton Bros., 133 N.L.R.B. 868 (1961); Terminal System, Inc., 127 N.I.R.B. 979 (1960).

12 The new agreement called for a wage increase of twenty-two cents an liour over a three year period. Fringe benefits were increased by an estimated twenty-seven cents an hour. 86 MoNTHLY LAB. REv. 69 (1963).

${ }^{13}$ President Kennedy's telegram of July 21, 1962, read in part: "Major strikes in this industry would substantially delay our vital missile and space program and would be contrary to the national defense interest. . . .

"In this important defense industry all parties have a responsibility to cooperate in achieving a settlement without any interruption of work. Accordingly, I request the parties to the disputes to continue work and operations for a period of sixty days with the status quo being preserved under all of the terms and conditions of the existing agreements. I further request the unions to withdraw all strike action during this period." Presidential Board of Distinguished Gitizens, Report of tile StUdy of Labor Disputes in the Aerospace Industry 1-2 (Sept. 1, 1962).

14 The Presidential Board was appointed on July 21, 1962, to supplement the efforts of the Federal Mediation and Conciliation Service. The Board was chaired by Dr. George W. Taylor, Professor of Industry, University of Pennsylvania, and former head of the War Labor Board. FMCS, SYNopsis of Presidential Bonkds of InQuiry Created Under National EMrergency Provisions of Labor Manatement Relations Acr, 1947 No. 22 (rev. Jan. 1963).

${ }^{15}$ The employees at Aerojet-General struck on October 2, 1962, after previously rejecting an employer proposal. The strike was only part of an industry wide crisis. Before the critical situation had been alleviated, eighty day Taft-Hartley injunctions were invoked at Republic Aircraft Corporation, Lockheed Aircraft Corporation, and the Boeing Company, and five separate boards were established by executive order to help solve disputes in the industry. Simkin, Aerospace Bargaining: Collective Bargaining Does Work, 14 LAB. L.J. 834, 835 (1963).

${ }^{10}$ Secretary Wirtz wired IAM President Hayes on October 2, 1962. The telegram, in part, stated: "This strike action constitutes an intolerable threat to the Nation's defense in view of the critical nature of Aerojet production as part of the missile program. You .... are hereby requested to be present at a meeting tomorrow...to 
Subsequently, the union membership rejected a proposal made by the employer and recommended by IAM; ${ }^{17}$ UMAT then filed an election petition. Since no contract existed at the time the petition was filed, the Regional Director, following clearly established Board precedent, ordered an election. ${ }^{18}$

In reversing the order, ${ }^{19}$ the NLRB rejected the Regional Director's ruling that the facts of the case failed to justify a denial of the employees' freedom of choice in the interest of industrial stability. ${ }^{20}$ The Board observed that the IAM, in yielding to the demands of the President and the Secretary of Labor, had surrendered, in the public interest, its right to strike while government intervention was pending. This surrender had removed an important source of union economic pressure, often needed to enforce demands advantageous to the union and to expedite a return to a contract protected status by speeding up negotiations. Furthermore, resorting to the more deliberate and compromising mechanisms of government mediation made employee dissatisfaction with the union more likely.21 Hence, the Board concluded that, if unions were faced with the possibility of representational challenges during

discuss and seek settlement of all disputed issues.... Failure to do so will mean their [IAM] necessary assumption of personal responsibility for weakening their Nation's defenses.... [T] ]heir hold-up of the defense program has no justification...." Brief for Intervenor, p. 5 .

174 CCH LAB. L. REP. at 19772. The proposal was rejected by combined vote of the employees at the employer's Sacramento and Azusa facilities. However, the employees at Azusa later accepted the proposal without change before the election petition was filed by the UMAT at the Sacramento plant.

${ }^{18}$ It is not clear that the Board shared the Regional Director's view that no agreement existed between the employer and IAM sufficient for election bar purposes. The Board declared that it would not hold that an entertainable question concerning representation had been raised merely because the "settlement" reached between the employer and the IAM "had not yet been consummated by a written agreement." 4 CCH LAB. L. REP. at 19773. One report emphasizes the importance of this interim agreement by inferring that it was a rationale behind the Aerojet decision. See 14 LAB. L.J. 878. If this interpretation is correct, the Aerojet case represents a substantial withdrawal from Appalachian Shale Prods. Co., 121 N.L.R.B. 1160 (1958), discussed supra note 4. The Board's reluctance to elaborate on this issue suggests that its language indicates nothing more than an attempt to cast the new policy against a most complimentary backdrop. The existence of the interim agreement should not be regarded as an important rationale behind the decision. See Groveton Papers Co., 96 N.L.R.B. 1369 (1951); Pittsburgh Corning Corp., 87 N.L.R.B. 647 (1949).

${ }^{10}$ Review was granted on the ground that a substantial question of law or policy was presented as to whether the election should be barred. 4 CCH LAB. L. REP. at 19771. Sce 29 C.F.R. $\$ 102.67$ (1963).

${ }^{20} 4$ CCH LAB. L. REP. at 19772.

${ }^{91}$ Id, at 19773 . 
a period of government intervention, they might well be unwilling to cooperate to the extent of sacrificing their right to strike. ${ }^{22}$ Thus, to entertain the election petition in the instant case would prove detrimental to future government efforts to effectuate peaceful settlements of disputes in the areospace industry. ${ }^{23}$

The Board's apprehension that unions, if faced with possible representational challenges, might not take part in government sponsored procedures ignores the reality that government intervention, accompanied by intense public pressure against production stoppage in this vital defense industry, substantially eliminates the unions' right to strike. ${ }^{24}$ Consequently, the only recourse in seeking improved contract terms is to accept government sponsored procedures. ${ }^{25}$

Although the fear expressed by the Board would not appear to be sufficient grounds for refusing to entertain the election petition in Aerojet, there are other compelling reasons for reaching this result. As the Board recognized, to entertain the rival election petition during the period of government intervention would be manifestly unfair, unduly penalizing the union for operating in an industry where a strike is not normally permitted. ${ }^{26}$ Another persuasive reason for not entertaining the petition is the possible unsettling

\footnotetext{
22 Ibid.

${ }^{23}$ Ibid.

24 Unions in the aerospace industry operating at companies which produce missile hardware are not legally prevented from striking, since they are outside the jurisdiction of the President's Missile Sites Labor Commission. Simkin, supra note 15, at 834. Nevertheless, government pressure has effectively nullified the use of the strike in the industry except when production demands are low. See Presidential Bosrd of Distinguished Citizens, op. cit. supra note 13 , at 18, 23-24. The only recent prolonged strike in the industry was a seventy-two day strike at a Republic Aviation Corporation plant in 1962. This plant produced a low priority jet fighter plane, however, and company operations there were about to be terminated. Simkin, stipra note 15 , at 835 .

25 One leading labor official has stressed the necessity of providing labor with a third party forum when unions are unable to strike to enforce their demands. Styles, Labor Relations in the Space Program, 14 LAB. L.J. 99, 100 (1963). Mr. Styles advocates the establishment of something akin to the War Labor Board to arbitrate disputes in the aerospace industry. Ibid. See note 31 infra.

${ }^{20} 4$ CCH LAB. L. REP. at 19773. Through no fault of the incumbent union, extrinsic circumstances have nulhified the strike right. Consequently, the incumbent union's ability to press for demands that would placate the union membership lias been diminished. This is especially true when such demands are for substantial departures from present employment conditions, since the mediatory process typically demands concessions from both sides. Thus, an incumbent union in an industry where the use of the strike has been effectively eliminated would seem to face a more severe task in thwarting internal dissension and disruption than does its counterpart in an industry where the strike may be effectively employed.
} 
effect of an election upon the results of government intervention, here the contract executed between the employer and the IAM after the UMAT's election petition was filed.

Under present NLRB rules it appears that if the Board had entertained the election petition, and the UMAT had won the election, the UMAT would have been free to make new demands and, under normal circumstances, strike to enforce them. ${ }^{27}$ The UMAT, apparently seeking to avoid this obstacle, advised the Board that it was willing to accept an election conditioned upon its assumption of the new contract. ${ }^{28}$

Refusing to rule upon whether it had the power to condition an election in this matter, ${ }^{29}$ the Board declared that such a determi-

${ }^{27}$ Hershey Chocolate Corp., 121 N.L.R.B. 901 (1958); American Seating Co., 106 N.L.R.B. 250 (1953). Although there is no direct holding that a union winning such an election may strike to enforce demands for contract changes, this is the logical implication of the above cases which held that a winning union could bargain for changes in the existing contract. Prior to the above cases the Board had held that it would not decide in a representational proceeding whether the representative to be certified would be required to assume the existing contract. Boston Mach. Works Co., 89 N.L.R.B. 59 (1950). See also Modine Mfgs. Co. v. Grand Lodge Int'l Ass'n of Machinists, 216 F.2d 326 (6th Cir. 1954). Thus, even though any union's right to strike appears illusory in the aerospace industry, demands by the UMAT for contract changes might have necessitated another period of government intervention.

ss 4 CCH LAB. L. REP. at 19773 n.8. The UMAT presumably feared that the Board might employ a "retroactive" contract bar rule under these special circumstances in order to protect the fruits of government intervention.

20 Whether the Board has the power to condition an election upon assumption of the existing contract is open to inquiry. Hershey Chocolate Corp., 121 N.L.R.B. 901 (1958), indicates that a rival union may voluntarily accede to a prior contract between the employer and the ousted incumbent after winning an election. See also Great Atl. \& Pac. Tea Co., 123 N.L.R.B. 1005 (1959) (assumption of existing contract condition precedent to consent election).

Under the Hershey rule, however, a petitioning union cannot be required to assume the existing contract as a condition precedent to a representation election. One reason for this mle is that the employees' freedom to choose their bargaining representative would have little meaning if the new bargaining representative could do no more than administer an old contract which failed to reflect the desires of the employees. On the other hand, if the petitioning union was not entitled to an election, because of a discretionary Board policy, but agreed in advance to submit to a conditioned election, the spirit of the Hershey rule would not be thwarted by ordering such an election. In this situation the employees' freedom of choice would not be abrogated, since the Board need not have allowed any election whatsoever.

Another difficulty in determining whether an election could be ordered on the condition of contract assumption is that under the Hershey rule, the incumbent union is also free to bargain for contract changes if it wins the election. The basis for this policy is the belief that the incumbent union should be placed at full parity with the rival union in the election campaign, unbound by the limitations of the existing contract in establishing a campaign platform. Where, however, the rival union has agreed to assume the existing contract, as a condition precedent to an election, there is no logical reason to allow a winning incumbent the right of up- 
nation was unnecessary. Any kind of election that might be held, by subjecting the incumbent union to possible replacement, would discourage it from accepting governmentally sponsored procedures. ${ }^{30}$ This perfunctory treatment of the contract assumption question seems insufficient in that the Board again emphasizes the necessity of insuring union acceptance of periods of government intervention. Because unions can presently be coerced into such acceptance anyway, allowing representational elections at this time would offer no significant threat to public efforts to insure production continuity in the industry. The Board could have presented a better reason for arriving at the same conclusion by frankly admitting that subjecting the incumbent union to possible replacement under these circumstances would be inequitable. Hence, even if the Board could protect the governmentally sired contract by conditioning an election upon the rival union's assumption of the contract, the basic objection of unfairness would not thereby be alleviated.

In evaluating the new bar rule formulated in the Aerojet case it is difficult to characterize its nature or to predict its future application. The new policy cannot be allied with the contract bar rule, since the major impact of the decision is not protection of the contract, but rather protection of the incumbent union as a cooperating entity. ${ }^{31}$ However, the NLRB's departure from generally accepted rules in holding that government intervention would act as a bar to an election was not wholly without precedent. During World War II it was held that when a labor dispute was submitted to the War Labor Board ${ }^{32}$ for arbitration, an election petition filed

setting a contract it has recently negotiated. See Petrowitz, The Effect of a Change of Bargaining Representative, 10 LAB. L.J. 845, 859-60 (1959). See generally Chamberlain, Collective Bargaining and the Concept of Contract, 48 ColuM. L. Rev. 829 (1948); Cox, The Legal Nature of Collective Bargaining Agreements, 57 Micr. L. Rev. 1 (1958); Shulman, Reason, Contract, and Law in Labor Relations, 68 HaRv. L. REv. 999 (1955).

304 CCF LAB. L. REP. at 19773.

${ }^{31}$ In this respect the new bar rule is somewhat analogous to the Board's onc year certification rule, which protects newly certified unions from representational challenges for a reasonable length of time-ordinarily one year. See Franks Bros. Co. v. NLRB, 321 U.S. 702 (1944), affirming 137 F.2d 989 (1st Cir. 1943), enforcing 44 N.L.R.B. 898 (1943); NLRB v. Prudential Ins. Co. of America, 154 F.2d 385 (6th Cir. 1946); Kimberly-Clark Corp., 61 N.L.R.B. 90 (1945); Monarch Aluminum Mfg. Co., 41 N.L.R.B. 1 (1942). The avowed purpose for this rule is to further industrial stability by promoting the bargaining relationship. Pragmatically this means that the newly certified union must be protected as an entity in order to foster a workable bargaining relationship.

${ }_{82}$ The War Labor Board was established by executive order on January 12, 1942 , and was terminated in the same manner on December 31, 1945. The Board, headed 
by a rival union would be dismissed even though no contract existed between the employer and the incumbent union at the time of filing. ${ }^{33}$ While the Aerojet case is too readily distinguishable from the War Labor Board cases to categorize the new bar rule as merely a modern version of those cases, ${ }^{34}$ the policy considerations motivating the respective decisions are similar. The Board adhered to the philosophy of protecting incumbent unions who of necessity cooperate with government efforts to avoid strikes and stabilize industrial relations in key defense industries. ${ }^{35}$

The Aerojet case demonstrates a willingness on the part of the Board to depart from rigid rules in the administration of labor policy when warranted in the public interest. ${ }^{36}$ By explicitly limiting the Aerojet decision to "the particular circumstances in this case,"37 the Board indicated that such departures would be on an ad hoc basis. Nothing, however, in the language or reasoning of the opinion prevents the new bar rule from being applied to similar situations arising in other critical defense industries.

by Dr. George Taylor, arbitrated over 20,000 labor disputes. Arbitration was voluntary, arising out of no-strike pledges in industry. Theoretically, its determinations had binding status only when accorded such by the parties. Strikes, however, usually resulted in government seizure and operation of the plant or factory involved. TAYLOR, GOVERNMENT REgulation of Industrial Relations 132-71 (1948).

${ }^{33}$ See, e.g., Aluminum Co. of America, 53 N.L.R.B. 593 (1943); Kennecott Copper Corp., 51 N.L.R.B. 1140 (1943); Allis-Chalmers Mfg. Co., 50 N.L.R.B. 306 (1943); cf. Corning Glass Works, 54 N.L.R.B. 963 (1944).

34 The War Labor Board cases, supra note 33, involved newly certified unions which were felt to have had no real opportunity to enjoy exclusive representation, whereas the IAM had been certified at Aerojet-General since 1944. A further distinguishing feature is that under arbitration the parties themselves generally cease to bargain over disputed issues and turn over the decision making responsibilities to the arbitrators. The mediation process, however, is designed merely to influence the course of collective bargaining between the parties by encouraging compromise. Thus, in the War Labor Board cases, the parties were awaiting the results of arbitration when the election petitions were filed while in Aerojet the parties were still bargaining when the UMAT filed its petition.

${ }^{35}$ Compare the Aerojet case with Kennecott Copper Corp., 51 N.L.R.B. 1140 (1943), where the Board stated: "An election at the present time might serve to negate the proceedings of the War Labor Board, require new proceedings before that Board, and create uncertainty and unsettled bargaining conditions for an additional indeterminate period. From the standpoint of stable labor relations, it is undesirable to penalize a statutory representative for unavoidable delays consequent upon its voluntary acceptance of orderly procedures established by governmental authority for the adjustment of differences with an employer." Id. at 1144.

so But see Friedin, supra note 1 , at 93 .

374 CCH LAB. L. REP. at 19773. In another aerospace industry case decided after Aerojet, Boeing Co., 144 N.L.R.B. No. 103 (1963), the Board held that the bargaining unit sought to be organized was inappropriate. The Board concluded that it was unnecessary to decide whether government intervention would act as a bar to an election petition filed by the rival union in that case. 
Wherever such situations arise, the element of voluntary cooperation would appear to be an essential requisite for the new policy's application..$^{38}$ However, the Board gave little guidance for facilitating a determination of what situations might warrant application of the new bar. ${ }^{39}$ The Board offered no definition of what constitutes government intervention or when such intervention becomes significant enough to justify imposition of the new policy. ${ }^{40}$ In addition, the Board failed to elaborate on whether a period of government intervention might indefinitely bar an election petition or whether it would act as a bar for only a limited period of time. ${ }^{41}$ Nor did the Board suggest a means by which the termination of such intervention might be calculated. ${ }^{\mathbf{2}}$ Apparently the Board pre-

${ }^{38}$ It could be argued that application of the new bar rule would still be warranted even when the element of "cooperation" is lacking, as, for example, during the life of a Taft-Hartley injunction. "The "cooperation" lauded by the Board is largely illusory. See Brief for Intervenor, p. 9 n.8. Whether government intervention takes direct or indirect forms, the equities are at least similar. In both instances the denial of the union's use of the strike may leave the union particularly vulnerable to representational challenges. See note 21 supra and accompanying text. However, it should be recognized that there may be greater justification for denying an election in terms of industrial stability when an incumbent union "cooperates" with government sponsored procedures.

so Obviously some type of government intervention into the collective bargaining process of a key defense industry must be present before the new bar rulc will be applicable.

10 Whether government intervention is present in an industry should be a question preliminary to a determination of whether that intervention acts as a bar to an election. The Board did not try to define what specific acts by what government officials might comprise significant government presence in the collective bargaining process. It is suggested that government intervention should act as a bar only when it is of such magnitude that the right to strike is eliminated as a practical matter. Mere attempts by government agencies, such as the Federal Mediation and Conciliation Service, to infuence the functioning of the bargaining process, where the right to strike is retained, clearly should not be viewed as government intervention significant enough to bar an election.

11 The determination of how long government intervention might act as a bar suggests three alternative solutions. First, government intervention might bar an election indefinitely. This would appear to usurp unreasonably the statutory right of employees to choose their bargaining representative. Secondly, a specific maximum length of time during which government intervention would act as a bar might be formulated. However, no suitable criteria seem to be available for establishing such a maximum period. The current three-year maximum bar period for contracts is not sufficiently analogous because contracts offer grenter stability of industrial relations and consequently justify a longer postponement of an election than does government intervention. The third and most desirable alternative is that government intervention would act to bar an election for a reasonable time only. The Board's flexible approach in the Aerojet case indicates that this course will be followed in the future.

12 Petitioner (UMAT) argned that government intervention at Aerojet-General had ended when its election petition was filed. Brief for Petitioner, p. 5-6. 
ferred to remain on a pragmatic basis, unbound by predeterminations and free to judge future cases on their individual merits. ${ }^{43}$

Characteristically, by refusing to exercise its power to order a representation election at Aerojet, the Board has attempted to facilitate the implementation of "other instruments of national labor policy" 44 within its sphere of influence.45 The question whether the new bar rule does complement the public policy of insuring maximum production in this industry is inextricably involved with the unique circumstances of individual cases. If employees are saddled with unpopular bargaining representatives resulting dissatisfaction may reduce plant morale and efficiency. This in turn may lower levels of production and, hence, tend to defeat the ultimate justification for government intervention. ${ }^{46}$ Even if the new bar rule successfully assists public efforts to prevent production stoppages, there is still the danger that, within the scope of its application, the new policy may encourage an even greater reliance on governmental formulas and discourage private solutions. The matter of increased government intrusion into this particular arena of collective bargaining, however, is not amenable to Board solution. Rather, the desirable extent of participation by the government in the collective bargaining process must be determined by more lofty echelons of national labor policy-making.

\$3 The landmark case of SEC v. Chenery Corp., 332 U.S. 194 (1947) legitimized an administrative agency's utilization of the ad hoc approach, despite the fact that such an approach is, of necessity, retroactive in application. See Leedom v. International Bhd. of Elec. Workers, 278 F.2d 237 (D.C. Cir. 1960) (retroactive application of new contract bar policy by NLRB not violative of constitutional due process). But cf. NLRB v. International Bhd. of Teamsters, 225 F.2d 343 (8th Cir. 1955) (party relying on previously unrenounced contract provision policy not guilty of unfair labor practice); NLRB v. Guy F. Atkinson Co., 195 F.2d I4l (9th Cir. 1952) (retroactive application of change in jurisdictional policy held abuse of discretion). For an outline of policy considerations which the author snggests should guide an administrative agency's determination of whether to incorporate an ad hoc approach, see Baker, Policy by Rule or Ad Hoc Approach-Which Should It Be?, 22 LAw \& ConTEMP. ProB. 658 (1957).

$\$ 4$ CCF LAB. L. REP. at 19773.

Eollowing the Supreme Court's directive in Southern S.S. Co. v. NLRB, 316 U.S. 31 (1942), reversing $120 \mathrm{~F} .2 \mathrm{~d} 505$ (3d Cir. 1941), the Board has refused to exercise its jurisdiction when to do so would interfere with other legitimate efforts, both public and private, to regulate labor relations. See, e.g., West Indian Co., 129 N.L.R.B. 1209 (1961) (certification of union by Virgin Islands agency held bar to representation election); Spielberg Mfg. Co., 112 N.L.R.B. 1080 (1955) (Board declined to exercise unfair labor practice jurisdiction in favor of private arbitration).

${ }^{40}$ See, e.g., Trailer Co. of America, 51 N.L.R.B. 1106 (1943). 